\title{
Pedagogical Analysis of the Baroque Period Piano Repertoire: Example of Italy
}

\author{
İzzet Yücetoker ${ }^{1}$ \\ ${ }^{1}$ School of Music Education, Marmara University, İstanbul, Turkey \\ Correspondence: İzzet Yücetoker, School of Music Education, Marmara University, İstanbul, Turkey.
}

Received: January 30, 2021

Accepted: July 25, 2021

Online Published: October 27, 2021

doi:10.5539/ies.v14n11p19

URL: https://doi.org/10.5539/ies.v14n11p19

\begin{abstract}
The aim of this study is to access editions of Italian Baroque works in place; to examine the availability of these works in terms of gaining techniques for playing in piano education, to gain new works aimed at different pedagogical stages in the field and to acquire new but unknown works in piano education repertoire. This research was carried out with the literature review model. During the first three months of the research, 158 baroque period composers were found among 2173 Italian composers. 50 composers composing on keyboard instruments were reached among 158 baroque composers. For this research study, the library of Dipartimento delle Arti dell'Universita di Bologna the Sala Borsa library, the Giovanni Martini Conservatory library and international museum and library of music in Bologna were visited and the works of composers made on the keyboard instruments were found. The number of works performed by composer on keyboard instruments is quite high. However, according to the objective of the project, it is aimed to perform pedagogical analysis by selecting one work from each composer. For analysis, created to the work evaluation forms prepared by the researcher. 50 works analyzed according to this form. While 48 Italian works can be used in piano education, 6 Italian works are not suitable for piano education. However, in order to use these works in piano education, these must be arranged from organ to pianoforte. An example of this is presented in this study.
\end{abstract}

Keywords: Baroque, Italian Baroque, Italian composers, music education, pianoforte

\section{Introduction}

Piano education refers to one of the sub-branches of instrument education. Piano education can be defined as the process of bringing changes in the cognitive, affective and kinesthetic behaviors of individuals through their own experiences with the help of teaching piano on the basis of the violin education definition made by Günay and Uçan (1980). Piano education is considered as an instrument education that has been recognized all around the world. In Turkey, piano education is demonstrated through private lessons and music classrooms as well as the music departments under universities. Piano lesson which is demonstrated as the main instrument or auxiliary instrument in the curriculum of state conservatories and fine arts faculties is also included in the curriculum of education faculties as seven semesters. According to Kutluk (1996), there are some reasons why piano education is provided in the departments of education faculties. These reasons are as follows:

1) A person playing a piano has the opportunity to develop oneself in very important fields of music such as grasping polyphony, sight-reading, musical hearing, harmony and form-wise informing.

2) The fact that the piano is an accompaniment instrument used for accompanying other instruments or human voices as well as being a self-contained solo instrument increase its importance in terms of instructional music teaching.

As in every field of education, the use of materials is also of great importance in terms of piano education. The instructor should select the works to be played by the student correctly and make them and also form the teaching steps without ignoring the cognitive, affective and psychomotor characteristics of the students. According to Gökbudak (2013), the selection of works should be performed as follows: "Students' learning situations require going beyond or below the aimed steps due to reasons such as instructor factor, practice opportunities and disciplines as well as individual differences such as levels of skill". The piano repertoire aimed on the basis of this definition could be expressed as a change according to the specific characteristics of the person.

Ertem (2011) stated that one of the most important tools is repertoire for acquiring and developing the desired 
behaviors, skills and achieving the anticipated goals regardless of piano education stage. However, the instructors encounter some problems when choosing a repertoire. Regarding this existing problem, Gültek $(2010$, p. 2$)$ stated that piano teachers have very limited sources written in their own languages and that these limited sources are, often, used without having a specific system. Given Gültek's comment on this issue, it could be stated that the instructors do not use different methods in the selection of works when determining the repertoire.

Many researchers have performed a due diligence on this issue when the repertoire studies are conducted in our country. According to the findings of research conducted by Kasap (2004) on 38 instructors in seven education faculties and the research conducted by Bulut (2005) on piano instructors in five education faculties, it was found that the baroque works taught in the piano education were only limited to the album named "Der Erste Bach". Also, in the doctorate study of Yücetoker (2014) it was stated that the education faculties in turkey mostly involved the works of German composers and students who studies in these faculties was barely familiar with baroque music of England and Italy. In the light of these determinations, it could be stated that baroque music works are not recognized and also, they are difficult to find in Turkey. Italy is a country which brought up many composers in Baroque music and was able to achieve to the development of this music form. As a result of a literature review it was determined that apart from Scarlatti and Corelli the works of other Italian baroque composers are not recognized and not used due to lack of repertoire in piano education repertoire of Turkey although there are at least 50 Italian keyboard composers.

Baroque music covers a period experienced between 1600 and 1750 in music history. The Baroque word is related to the Portuguese word of Barocco and is a movement born in reaction to Renaissance art in the first place and it is primarily originated in Italy. Because there were no piano instruments at that time, the composers of that period wrote their works for keyboard instruments such as organ, clavichord, and so on, which were later adapted by the arrangers for the piano (Selanik, 1996). It could be stated that these adaptations are the most basic works that could be trained in piano lessons provided in both conservatories and music education faculties as a required course under the roof of music education. Because baroque works help the students to: develop baroque style concept by avoiding rhythmic changes and making soft nuances without exaggeration, teach the polyphony concept used in baroque music, teach the ornaments, understand the counterpoint technique, follow the theme structure and theme, apprehend the coordination of two hands, develop the skills to announce two and three audio batches on one hand, teach the studying of retention audios with a good legato technique, develop the touch command, improve concentration gradually, earn the technique of playing as if singing a song, develop the musical expression and thought, baroque works also have an important structure for education because of the features such as earning disciplined training and developing previously acquired skills due to the difficulties of the works (Eskioğlu, 2003). For these reasons, baroque works are believed to have an important place in piano education.

According to research studies, it is observed that baroque period works in which a student earns such important knowledge and skills are repeated in the cycle of similar works due to lack of sources education faculties in our country. The German baroque style is undoubtedly of great importance. For this reason, works of German composers such as Bach and Handel are played in the music education departments. However, there are also composers who had lived in Italy and had produced very important works for baroque piano literature. Although these composers are not well known in the Turkish education system, it is believed that they have an important place in piano education.

It is thought that repertoire selection which is one of the important elements of piano education has a capital importance in changing the attitude of students towards piano education and harmonizing the behaviors aimed to gain in piano education with the cognitive and psychomotor developments of the students. According to Özmenteş (2013), effective repertoire selection is important in addition to many factors as a means of ensuring student motivation. In addition, according to questionnaire results applied to students by Ekinci and Demirtaş (2013) it was stated that some of the baroque period works used were not appropriate for the student levels and that students wanted to play different baroque works because of the continuous repetition of the works used in education.

While determining the repertoire in piano education, it is necessary to determine the exact target behaviors to be acquired as well as the attitudes and motivations of the students. Ertem (2011) believes that "the instructors should consider the students' level of readiness, physical structures and technical levels while determining the repertoire". In addition to this, the fact that the baroque period works which should be used in the piano education are not adequate and students play the works of a limited number of composers limits the course willingness of the students and instructors. Longyear (1970) believed that "only the works of the eminent and famous composers are performed while the repertoire works are selected". According to this situation, it is important for the instructors to search for the works of less known composers that have importance for the diversity of piano education repertoire as well as the works of famous composers and to add these works to their repertoires. 
The aim of this study is to access editions of Italian Baroque works in place; to examine the availability of these works in terms of gaining techniques for playing in piano education, to gain new works aimed at different pedagogical stages in the field and to acquire new but unknown works in piano education repertoire.

\subsection{Research Focus}

When the determinations resulting from the different studies conducted for piano education repertoire implemented in Turkey, it is seen that the most widely used works among baroque repertoire are the works of J. S. Bach and Handel. These two composers are of German origin and they are thought to have the same effects on their works and that the characters of the works resemble each other since they lived in the same period. However, according to Camp (1992), "it is important to select works containing different style features belonging to various periods and to play the works in various characters to the students in the selection of repertoire." Therefore, it is observed that the most important point neglected in selecting the works of baroque period with regard to piano education implemented in music departments in Turkey is constraint on repertoire.

\section{Method}

This research was carried out with the literature review model. During the first three months of the research, 158 baroque period composers were found among 2173 Italian composers. 50 composers composing on keyboard instruments were reached among 158 baroque composers. For this research study, the library of Dipartimento delle Arti dell'Universita di Bologna the Sala Borsa library, the Giovanni Martini Conservatory library and international museum and library of music in Bologna were visited and the works of composers made on the keyboard instruments were found. The number of works performed by composer on keyboard instruments is quite high. However, according to the objective of the project, it is aimed to perform pedagogical analysis by selecting one work from each composer. For this reason, interviews were held with the instructors named Marco ARLOTTI, Maurizio BUSI, Francesco DILAGHI, Gabrio FANTI, Maura LANDI, Fabrizio LANZONI and Carlo MAZZOLI who were serving in the Bologna Conservatory in order to understand which works should be used in education. In addition, the views of Professor Elisabetta PASQUINI, my adviser, were frequently consulted throughout the progress of my project. As a result of the interviews, I have completed pedagogical analysis applied on each work of 50 baroque composers given in the following list and arrangements made on piano works from org works.

Only the number of composers only living in the baroque period is 158 . But my investigation is dedicated to only Italian keyboard composers in the Baroque period. Because of this review, I found 50 Italian keyboard composers. The names of these composers are offered in alphabetical order. AGNESI Maria Teresa, ALBERTI Domenico, ARAJA Francesco, ARRESTI Floriano, ARRESTİ Giulio Cesare, BARSANTI Francesco, BENEVOLİ Orazio, BESSEGHI Angelo Michele, CASINII Giovanni Maria, CIRRI Ignazio, COTUMACCI Carlo, DELLA CIAJA Azzolino Bernardino, DRAGHI Giovanni Battista, DURANTE Francesco, FASOLO Giovanni Battista, FATTORINI Gabriele, FERRINI Giovanni Battista, FIORILLO Ignatio, FONTANA Fabrizio, FRANCESCO Nicolo, FRESCOBALDI Girolamo, GALUPPI Baldassare, GASPARINI Francesco, GIUSTINI Lodovico, GRECO Gaetano, LAPIS Santo, LUZZASCHI Luzzasco, MANCINI Francesco, MANFREDINI Vincenzo, MARCELLO Benedetto, MARTINI Giovanni Battista, MERULA Tarquinio, MAYONE Ascanio, PARADIES Pietro Domenico, PASQUALI Nicolo, PASQUINI Bernardo, PELLEGRINI Ferdinando, PERGOLESI Giovanni Battista, POGLIETTI Alessandro, POLLAROLO Carlo Francesco, PORPORA Nicola Antonio, ROSSI Michelangelo, SCARLATTI Alessandro, SCARLATTI Domenico, SELLITTO Giacomo, SERINI Giovanni Battista, SERTORI Girolamo, STORACE Bernardo, TARABACI Giovanni Maria, ZIPOLI, Domenico.

\subsection{Instrument and Procedures}

The overall objective of this research, the introduction of Italian baroque works in Turkey and intended for use in the Turkish piano education system. There for, the works of the Italian baroque organ composers arranged to use the piano. These works organized according to the necessary educational attitudes. These arrangements made according to the work evaluation forms prepared by the researcher. It is like that step's development of the work of baroque evaluation form.

The work of evaluation form is designed to determine the behaviors to be taught to a student in a Baroque work and to support it with expert opinions. While preparing the work evaluation form, the researcher created the criterion including technical and musicality features of the Baroque period works by reviewing the field literature and expert opinions. In order to be able to make the content validity of the work evaluation form consisting of 14 articles, it was sent to 13 piano instructors working at different universities. The instructors were requested to grade the options as 3 if necessary, 2 if Useful/Insufficient and 1 if Unnecessary. The assessment scale received from the experts was calculated with the content validity ratios developed by Lawshe (1975). 
This approach, known as the Lawshe (1975) technique, consists of 6 steps. Establishment of field experts' group, preparation of candidate scale forms, obtaining expert opinions, obtaining content validity ratios for articles, obtaining content validity indexes for scale, establishment of the required forms according to the content validity/index criteria ( Yurdugul, 2005).

\subsection{Data Analysis}

The answers taken from the instructors are individually calculated according to the above formula and the results are shown in Table 1.

Table 1. Experts' opinions and content validity ratios for work evaluation form

\begin{tabular}{lcccc}
\hline Pedagogical Achievements & Necessary & Useful/Insufficient & Unnecessary & Content Validity Rations \\
\hline Teaching "portato" technique, & 13 & - & - & 1.00 \\
Teaching "ornaments", & 13 & - & - & 1.00 \\
Teaching "counterpoint" structure, & 13 & - & - & 1.00 \\
"Polyphony" understanding, & 12 & 1 & - & 0.84 \\
Teaching "follow themes", & 13 & - & 5 & -00 \\
Teaching "theme tracking", & 5 & 3 & - & -0.23 \\
"Two-hand coordination" development, & 12 & 1 & - & 0.84 \\
In teaching "how to play two sounds in one hand", & 13 & - & - & 0.00 \\
Teaching "how to play three sounds in one hand", & 12 & 1 & 5 & 1.00 \\
In the development of "legato" playback, & 13 & - & - & 0.07 \\
Develop musical expression and musical thinking skills, & 7 & 1 & - & 0.69 \\
Improving the ability to easily highlight complex themes, & 11 & 2 & - & 0.84 \\
Developed silent transit technique on the work, & 12 & 1 & 1 & 0.84 \\
Improving the ability to easily sight reading. & 12 & & - & \\
\hline
\end{tabular}

Table shows the answers given by the lecturers to the evaluation form and the content validity ratios and indexes of these answers. Lawshe (1975) identified the validity scale of 13 experts as 0.54 . Therefore, as the articles 7 and 12, of the scale prepared as 14 articles were under the content validity criteria, they were removed from the measurement tool and 12 articles remained. It can be said that the scale is statistically meaningful as the content validity index of the measurement tool is 0.69 . In short, the issue whether or not to use Italy Baroque works in piano education was evaluated in 12 pedagogical achievements.

\section{Results}

According to the first results of the research, the composers had been written numerous works particularly for keyboard instruments. For this reason, I selected solely one piece from every composer. While choosing works, I paid attention to pedagogical features, melody features, playing features on the piano. When the works were examined, we could see perfect counterpoint features, portato and legato plays features, various ornaments, two and three sounds for one hand. Thus, the use of these works in education has been determined.

According to my experiments, organists play these works on the keyboard in Italy. Also, students who are educated in conservatory, play these works on the keyboard as well. Because there are no other keyboard instruments except for the pianoforte in conservatory of Turkey, the arrangement of these works for piano is very important. When these works have been arranged for the piano, Turkey music education institutions will be gained newly repertoires.

In the last term of this research, Italian baroque period works for keyboard were edited for piano instrument. Until now, I found 50 Italian keyboard composers. When the notes were examined, we could see that these works are difficult to play on the piano for students. This is because there are not portato, legato, number of fingers, staccato, crescendo, decrescendo, etc. in these keyboard works. So, I arranged these works from organ to piano. The sample of Pietro Domenico Paradies's Toccata in A Major is examined, we could see. 

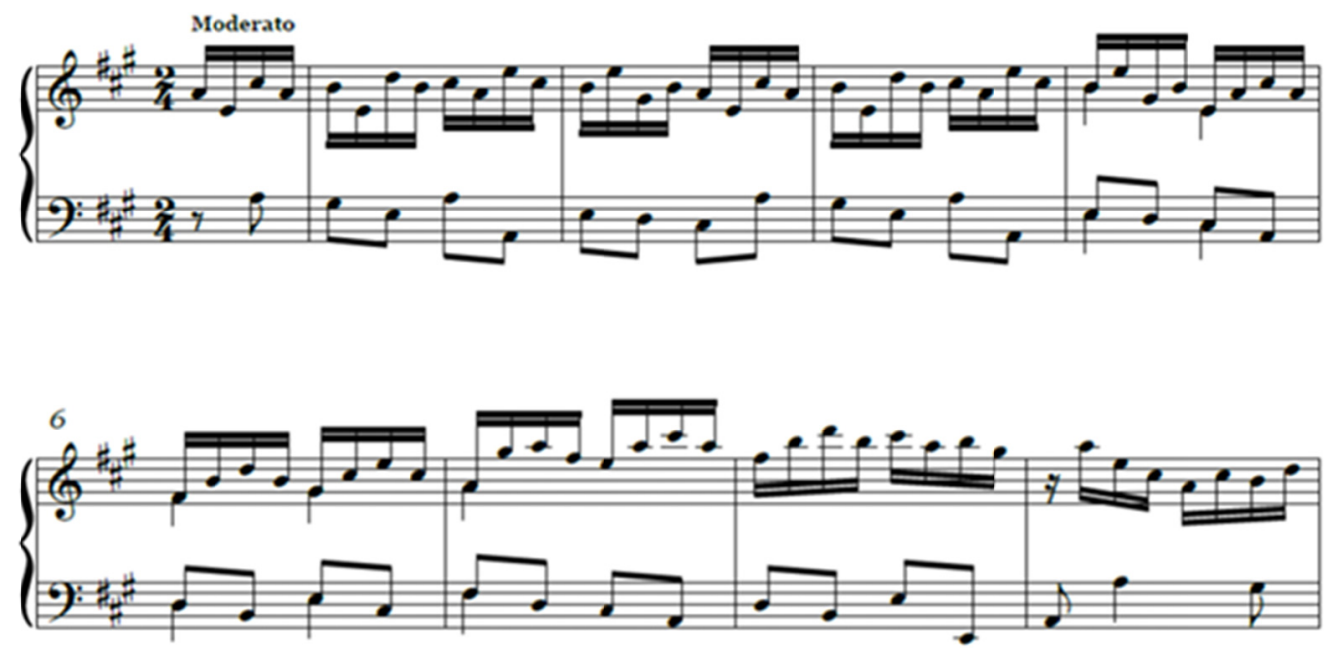

Figure 1. The samples of Pietro Domenico PARADIES's Toccata in a major for organ

As seen on the sample that, there are no finger number, portato, staccato, legato marks etc.
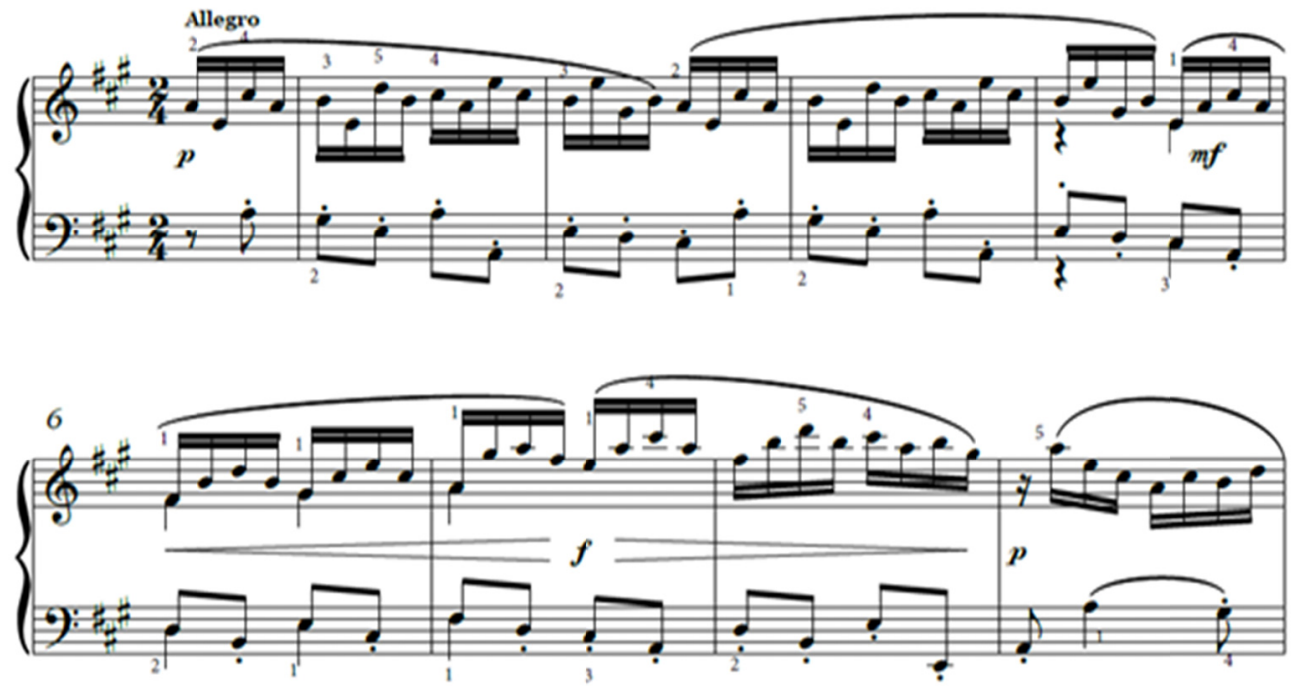

Figure 2. The samples of Pietro Domenico PARADIES's Toccata in a major for pianoforte (Edited by researcher)

As seen on the sample that, there are finger number, portato, staccato, legato marks etc.

Table 2. List of pedagogical achievements for pianoforte in the works of Italian baroque composers

\begin{tabular}{cccc}
\hline Number & Pedagogical Achievements & Number & Pedagogical Achievements \\
\hline 1 & Portato technique & 7 & Legato technique \\
2 & Polyphony concept & 8 & Playing three sound parties in one hand \\
3 & Teaching ornaments & 9 & Use of many themes \\
4 & Teaching counterpoint structure & 10 & Silent finger crossing \\
5 & Teaching to follow the theme & 11 & Easy sight-reading \\
6 & Two sound parties in one hand & 12 & Developing two-hand coordination \\
\hline
\end{tabular}

The following table shows the pedagogical achievements of the works of 50 Italian composers. The pedagogical achievements of the works are given as abbreviated numbers according to the numbers in Table 2. The composer's 
works were selected by random method.

Table 3. Pedagogical analysis of the Italian baroque composers and works

\begin{tabular}{|c|c|c|c|c|c|}
\hline \multirow{2}{*}{ Composers Name } & \multirow{2}{*}{ Title of Work } & \multicolumn{2}{|c|}{ Pedagogical Achievements } & \multicolumn{2}{|c|}{ Can it be used in piano education? } \\
\hline & & Exist & Don't exist & Yes & No \\
\hline M. Teresa Agnesi & Sonata in F major & $1,2,3,5,6,7,9,10,11,12$ & 4,8 & $\mathrm{X}$ & \\
\hline Domenico Alberti & Sonata in $\mathrm{g}$ minor & $1,2,3,4,5,7,9,10,11,12$ & 5,8 & $\mathrm{X}$ & \\
\hline F. Domenico Araja & Capriccio & $2,7,9,12$ & $1,3,4,5,6,8,10,11$ & & $\mathrm{X}$ \\
\hline Floriano Arresti & Ricercare & $1,2,3,4,5,6,7,9,10,12$ & 8,11 & $\mathrm{X}$ & \\
\hline G. Cesare Arresti & Sonata in a minor & $1,2,4,5,6,7,9,12$ & $3,8,10,11$ & $\mathrm{X}$ & \\
\hline Francesco Barsanti & The Lady Erskine & $1,2,7,9,10,11,12$ & $3,4,5,6,8$ & $\mathrm{X}$ & \\
\hline Orazio Benevoli & Prelude & $2,4,5,6,7,9,10,11,12$ & $1,3,8$ & $\mathrm{X}$ & \\
\hline A. Michele Besseghi & Prelude & $1,2,3,4,5,7,9,11,12$ & $6,8,10$ & $\mathrm{X}$ & \\
\hline G.Maria Casini & Pensieri for Organ & $1,2,3,4,5,6,7,8,9,10,11,12$ & - & $\mathrm{X}$ & \\
\hline Ignazio Cirri & Sonata in $\mathrm{g}$ minor & $1,2,4,5,6,7,8,9,10,12$ & 3,11 & $\mathrm{X}$ & \\
\hline Carlo Cotumacci & Toccata & $1,2,3,6,7,9,11,12$ & $4,5,8,10$ & $\mathrm{X}$ & \\
\hline A. Bernarddino Ciaja & Sonata & $1,2,3,4,5,6,7,9,10,11,12$ & 8 & $\mathrm{X}$ & \\
\hline G. Battista Draghi & Suite & $1,2,3,4,5,6,7,9,10,11,12$ & 8 & $\mathrm{X}$ & \\
\hline Francesco Durante & Partita & $1,2,3,4,5,6,7,9,10,11,12$ & 8 & $\mathrm{X}$ & \\
\hline G. Battista Fasolo & Canzone & $1,2,4,5,6,7,8,9,10,12$ & 3,11 & $\mathrm{X}$ & \\
\hline Gabriele Fattorini & Ricerica & $2,6,7,8,12$ & $1,3,4,5,9,10,11$ & & $\mathrm{X}$ \\
\hline G. Battista Ferrini & Ballo di Mantova & $1,2,3,4,5,6,7,9,10,11,12$ & 8 & $\mathrm{X}$ & \\
\hline Ignazio Fiorillo & Sonata a minor & $1,2,5,6,7,9,10,11,12$ & $3,4,8$ & $\mathrm{X}$ & \\
\hline Fabrizio Fontana & Ricerica & $2,4,7,10$ & $1,3,5,6,8,9,11,12$ & & $\mathrm{X}$ \\
\hline Nicola Frencesco & Toccata & $1,2,3,4,5,6,7,9,10,11,12$ & 8 & $\mathrm{X}$ & \\
\hline Girolamo Frescobaldi & Aria and variations & $1,2,3,4,5,6,7,8,9,10,11,12$ & - & $\mathrm{X}$ & \\
\hline Baldassare Galuppi & Allegro & $1,2,3,4,5,7,9,10,11,12$ & 6,8 & $\mathrm{X}$ & \\
\hline Francesco Gasparini & Sonata in $\mathrm{d}$ minor & $1,2,3,4,5,6,7,9,10,11,12$ & 8 & $\mathrm{X}$ & \\
\hline Lodovico Giustini & Sonata VII & $1,2,3,4,5,6,7,9,10,11,12$ & 8 & $\mathrm{X}$ & \\
\hline Gaetano Greco & Selection of pieces & $1,2,3,4,5,6,7,8,9,10,11,12$ & - & $\mathrm{X}$ & \\
\hline Santo Lapis & Sonata in G major & $1,2,3,4,7,7,9,11,12$ & $5,6,8,10$ & $\mathrm{X}$ & \\
\hline Luzzaco Luzzaschi & Toccata & $2,4,6,7,12$ & $1,3,5,8,9,10,11$ & & $\mathrm{X}$ \\
\hline Francesco Mancini & Toccata & $1,2,3,4,5,6,7,9,10,11,12$ & 8 & $\mathrm{X}$ & \\
\hline Vincenzo Manfredini & Fugue & $1,2,4,5,6,7,8,9,10,12$ & 3,11 & $\mathrm{X}$ & \\
\hline Benedetto Marcello & Sonata III & $1,2,3,4,5,6,7,9,10,11,12$ & 8 & $\mathrm{X}$ & \\
\hline G. Battista Martini & Sonata in $\mathrm{c}$ minor & $1,2,3,4,5,6,7,9,10,11,12$ & 8 & $\mathrm{X}$ & \\
\hline Acanio Mayone & Ricercare & $2,4,6,7,12$ & $1,3,5,8,9,10,11$ & & $\mathrm{X}$ \\
\hline Tarquinio Merula & Cromatica Terzo & $1,2,4,5,6,7,9,12$ & $3,8,10,11$ & $\mathrm{X}$ & \\
\hline Domenico Paradies & Toccata & $1,2,3,4,5,6,7,9,10,11,12$ & 8 & $\mathrm{X}$ & \\
\hline Nicolo Pasquali & Lesson VIII & $1,2,3,4,5,7,11,12$ & $6,8,9,10$ & $\mathrm{X}$ & \\
\hline Bernardo Pqsquini & Toccata & $1,2,4,5,6,7,8,9,11,12$ & 3,10 & $\mathrm{X}$ & \\
\hline Ferdinando Pellegrini & Sonata VI & $2,5,6,7,9,11,12$ & $1,3,4,8,10$ & $\mathrm{X}$ & \\
\hline G. Battista Pergolesi & Sonata in A Major & $1,2,3,4,5,7,9,11,12$ & $6,8,10$ & $\mathrm{X}$ & \\
\hline Alessandro Poglietti & Ricercare & $1,2,4,7,9,12$ & $3,5,6,8,10,11$ & $\mathrm{X}$ & \\
\hline Francesco Pollarolo & Sonata & $1,2,4,5,6,7,8,12$ & $3,9,10,11$ & $\mathrm{X}$ & \\
\hline N. Antonio Porpora & Fugue & $1,2,4,5,6,7,9,12$ & $3,8,10,11$ & $\mathrm{X}$ & \\
\hline Michelangelo Rossi & Toccata & $1,2,4,6,7,12$ & $3,5,8,9,10,11$ & $\mathrm{X}$ & \\
\hline Domenico Scarlatti & Sonata K.149 & $1,2,3,4,5,6,7,9,10,11,12$ & 8 & $\mathrm{X}$ & \\
\hline Alessandro Scarlatti & Toccata & $1,2,3,4,5,7,9,11,12$ & $6,8,10$ & $\mathrm{X}$ & \\
\hline Giacomo Sellitto & Fugue & $1,2,3,4,5,6,7,9,11,12$ & 8,10 & $\mathrm{X}$ & \\
\hline Giovanni Serini & Sonata in $\mathrm{C}$ major & $2,3,7,9,12$ & $1,4,5,6,8,10,11$ & & $\mathrm{X}$ \\
\hline Girolamo Sertoni & Toccata & $1,2,3,4,5,6,7,9,11,12$ & 8,10 & $\mathrm{X}$ & \\
\hline Bernardo Storace & Toccata & $1,2,3,4,5,6,7,9,12$ & $8,10,11$ & $\mathrm{X}$ & \\
\hline G.Maria Trabaci & Galliard I & $1,2,3,4,7,9,11,12$ & $5,6,8,10$ & $\mathrm{X}$ & \\
\hline Domenico Zipoli & Partita & $1,2,3,4,5,6,7,9,10,11,12$ & 8 & $\mathrm{X}$ & \\
\hline
\end{tabular}




\section{Discussion}

It has been concluded that the Maria Teresa Agnesi's "Sonata in F Major" can be reorganized for the piano instrument and be used in the education as this work will bring the skills such as playing portato, playing legato, learning polyphony concept, doing ornaments, following themes, playing two sounds in one hand, sounding different themes used at the same time, doing silent finger cross, improving the ability to sight-read and improving the two-hand coordination for the students.

- It has been concluded that the Domenico Alberti's "Sonata in g Minor" can be reorganized for the piano instrument and be used in the education as this work will bring the skills such as playing portato, playing legato, learning polyphony concept, doing ornaments, learning counterpoint technique, following themes, sounding different themes used at the same time, doing silent finger cross, improving the ability to sight-read and improving the two-hand coordination for the students.

- It has been concluded that even if the Francesco Domenico Araja's "Capriccio in A Major" reorganized for the piano instrument, this piece would not be suitable for piano education because of the lack of pedagogical achievements.

- It has been concluded that the Floriano Arresti's "Ricercare" can be reorganized for the piano instrument and be used in the education as this work will bring the skills such as playing portato, playing legato, learning polyphony concept, doing ornaments, learning counterpoint technique, following themes, playing two sounds in one hand, playing three sounds in one hand, sounding different themes used at the same time, doing silent finger cross, and improving the two-hand coordination for the students.

- It has been concluded that the Giulio Cesare's "Sonata in a Minor" can be reorganized for the piano instrument and be used in the education as this work will bring the skills such as playing portato, playing legato, learning polyphony concept, learning counterpoint technique, following themes, playing two sounds in one hand, sounding different themes used at the same time, and improving the two-hand coordination for the students.

- It has been concluded that the Francesco Barsanti's "Lady Erskine" can be reorganized for the piano instrument and be used in the education as this work will bring the skills such as playing portato, playing legato, learning polyphony concept, sounding different themes used at the same time, doing silent finger cross, improving the ability to sight-read and improving the two-hand coordination for the students.

- It has been concluded that the Orazio Benevoli's "Prelude" can be reorganized for the piano instrument and be used in the education as this work will bring the skills such as, playing legato, learning polyphony concept, learning counterpoint technique, following themes, playing two sounds in one hand, sounding different themes used at the same time, doing silent finger cross, improving the ability to sight-read and improving the two-hand coordination for the students.

- It has been concluded that the Angelo Michele Besseghi's "Prelude" can be reorganized for the piano instrument and be used in the education as this work will bring the skills such as playing portato, playing legato, learning polyphony concept, doing ornaments, learning counterpoint technique, following themes, sounding different themes used at the same time, improving the ability to sight-read and improving the two-hand coordination for the students.

- It has been concluded that the Giovanni Maria Casini's "Pensieri" can be reorganized for the piano instrument and be used in the education as this work will bring the skills such as playing portato, playing legato, learning polyphony concept, doing ornaments, learning counterpoint technique, following themes, playing two sounds in one hand, playing three sounds in one hand, sounding different themes used at the same time, doing silent finger cross, improving the ability to sight-read and improving the two-hand coordination for the students.

- It has been concluded that the Ignazio Cirri's "Sonata in g Minor" can be reorganized for the piano instrument and be used in the education as this work will bring the skills such as playing portato, playing legato, learning polyphony concept, learning counterpoint technique, following themes, playing two sounds in one hand, sounding different themes used at the same time, doing silent finger cross, playing three sounds in one hand and improving the two-hand coordination for the students.

- It has been concluded that the Carlo Cotumacci's "Toccata" can be reorganized for the piano instrument and be used in the education as this work will bring the skills such as playing portato, playing legato, learning polyphony concept, doing ornaments, playing two sounds in one hand, sounding different themes used at the same time, , improving the ability to sight-read and improving the two-hand coordination for the students. 
- It has been concluded that the Azzolino Bernardino Della Ciaja's "Sonata" can be reorganized for the piano instrument and be used in the education as this work will bring the skills such as playing portato, playing legato, learning polyphony concept, doing ornaments, learning counterpoint technique, following themes, playing two sounds in one hand, sounding different themes used at the same time, doing silent finger cross, improving the ability to sight-read and improving the two-hand coordination for the students.

- It has been concluded that the Giovanni Battista Draghi's "Suite" can be reorganized for the piano instrument and be used in the education as this work will bring the skills such as playing portato, playing legato, learning polyphony concept, doing ornaments, learning counterpoint technique, following themes, playing two sounds in one hand, sounding different themes used at the same time, doing silent finger cross, improving the ability to sight-read and improving the two-hand coordination for the students.

- It has been concluded that the Francesco Durante's "Partita" can be reorganized for the piano instrument and be used in the education as this work will bring the skills such as playing portato, playing legato, learning polyphony concept, doing ornaments, learning counterpoint technique, following themes, playing two sounds in one hand, sounding different themes used at the same time, doing silent finger cross, improving the ability to sight-read and improving the two-hand coordination for the students.

- It has been concluded that the Giovanni Battista Fasolo's "Canzone" can be reorganized for the piano instrument and be used in the education as this work will bring the skills such as playing portato, playing legato, learning polyphony concept, learning counterpoint technique, following themes, playing two sounds in one hand, playing three sounds in one hand, sounding different themes used at the same time, doing silent finger cross and improving the two-hand coordination for the students.

- It has been concluded that even if the Gabriele Fattorini's Ricerica reorganized for the piano instrument, this piece would not be suitable for piano education because of the lack of pedagogical achievements.

- It has been concluded that the Giovanni Battista Ferrini's "Ballo di Mantova" can be reorganized for the piano instrument and be used in the education as this work will bring the skills such as playing portato, learning counterpoint technique, playing legato, learning polyphony concept, doing ornaments, following themes, playing two sounds in one hand, sounding different themes used at the same time, doing silent finger cross, improving the ability to sight-read and improving the two-hand coordination for the students.

- It has been concluded that the Ignazio Fiorillo's "Sonata in a Minor" can be reorganized for the piano instrument and be used in the education as this work will bring the skills such as playing portato, playing legato, learning polyphony concept, following themes, playing two sounds in one hand, sounding different themes used at the same time, doing silent finger cross, improving the ability to sight-read and improving the two-hand coordination for the students.

- It has been concluded that even if the Fabrizio Fontana's "Ricerica" reorganized for the piano instrument, this piece would not be suitable for piano education because of the lack of pedagogical achievements.

- It has been concluded that the Nicola Francesco's "Toccata" can be reorganized for the piano instrument and be used in the education as this work will bring the skills such as playing portato, playing legato, learning polyphony concept, doing ornaments, learning counterpoint technique, following themes, playing two sounds in one hand, sounding different themes used at the same time, doing silent finger cross, improving the ability to sight-read and improving the two-hand coordination for the students.

- It has been concluded that the Girolamo Frescobaldi's “Aria with Variations" can be reorganized for the piano instrument and be used in the education as this work will bring the skills such as playing portato, playing legato, learning polyphony concept, doing ornaments, learning counterpoint technique, following themes, playing two sounds in one hand, playing three sounds in one handsounding different themes used at the same time, doing silent finger cross, improving the ability to sight-read and improving the two-hand coordination for the students.

- It has been concluded that the Baldassare Galuppi's "Allegro" can be reorganized for the piano instrument and be used in the education as this work will bring the skills such as playing portato, playing legato, learning polyphony concept, doing ornaments, learning counterpoint technique, following themes, sounding different themes used at the same time, doing silent finger cross, improving the ability to sight-read and improving the two-hand coordination for the students.

- It has been concluded that the Francesco Gasparini's "Sonata in d Minor" can be reorganized for the piano instrument and be used in the education as this work will bring the skills such as playing portato, playing legato, learning polyphony concept, doing ornaments, learning counterpoint technique, following themes, 
playing two sounds in one hand, sounding different themes used at the same time, doing silent finger cross, improving the ability to sight-read and improving the two-hand coordination for the students.

- It has been concluded that the Lodovico Giustini's "Sonata VII" can be reorganized for the piano instrument and be used in the education as this work will bring the skills such as playing portato, playing legato, learning polyphony concept, doing ornaments, learning counterpoint technique, following themes, playing two sounds in one hand, sounding different themes used at the same time, doing silent finger cross, improving the ability to sight-read and improving the two-hand coordination for the students.

- It has been concluded that the "Gaetano Greco's Selection of Pieces" can be reorganized for the piano instrument and be used in the education as this work will bring the skills such as playing portato, playing legato, learning polyphony concept, doing ornaments, learning counterpoint technique, following themes, playing two sounds in one hand, playing three sounds in one hand, sounding different themes used at the same time, doing silent finger cross, improving the ability to sight-read and improving the two-hand coordination for the students.

- It has been concluded that the Santo Lapis's "Sonata in G Major" can be reorganized for the piano instrument and be used in the education as this work will bring the skills such as playing portato, playing legato, learning polyphony concept, doing ornaments, learning counterpoint technique, sounding different themes used at the same time, improving the ability to sight-read and improving the two-hand coordination for the students.

- It has been concluded that even if the Luzzaco Luzzaschi's "Toccata" reorganized for the piano instrument, this piece would not be suitable for piano education because of the lack of pedagogical achievements.

- It has been concluded that the Francesco Mancini's "Toccata" can be reorganized for the piano instrument and be used in the education as this work will bring the skills such as playing portato, playing legato, learning polyphony concept, doing ornaments, learning counterpoint technique, following themes, playing two sounds in one hand, sounding different themes used at the same time, doing silent finger cross, improving the ability to sight-read and improving the two-hand coordination for the students.

- It has been concluded that the Vincenzo Manfredini's "Fugue" can be reorganized for the piano instrument and be used in the education as this work will bring the skills such as playing portato, playing legato, learning polyphony concept, learning counterpoint technique, following themes, playing two sounds in one hand, playing three sounds in one hand sounding different themes used at the same time, doing silent finger cross, and improving the two-hand coordination for the students.

- It has been concluded that the Benedetto Marcello's "Sonata III" can be reorganized for the piano instrument and be used in the education as this work will bring the skills such as playing portato, playing legato, learning polyphony concept, doing ornaments, learning counterpoint technique, following themes, playing two sounds in one hand, sounding different themes used at the same time, doing silent finger cross, improving the ability to sight-read and improving the two-hand coordination for the students.

- It has been concluded that the Giovanni Battista Martini's "Sonata in c Mino"r can be reorganized for the piano instrument and be used in the education as this work will bring the skills such as playing portato, playing legato, learning polyphony concept, doing ornaments, learning counterpoint technique, following themes, playing two sounds in one hand, sounding different themes used at the same time, doing silent finger cross, improving the ability to sight-read and improving the two-hand coordination for the students.

- It has been concluded that even if the Acanio Mayone's "Ricercare" reorganized for the piano instrument, this piece would not be suitable for piano education because of the lack of pedagogical achievements.

- It has been concluded that the Tarquinio Merula's "Intonaziona Cromatica del Terzo Tono" can be reorganized for the piano instrument and be used in the education as this work will bring the skills such as playing portato, playing legato, learning polyphony concept, learning counterpoint technique, following themes, playing two sounds in one hand, sounding different themes used at the same time and improving the two-hand coordination for the students.

- It has been concluded that the Pietro Domenico Paradies's "Toccata" can be reorganized for the piano instrument and be used in the education as this work will bring the skills such as playing portato, playing legato, learning polyphony concept, doing ornaments, learning counterpoint technique, following themes, playing two sounds in one hand, sounding different themes used at the same time, doing silent finger cross, improving the ability to sight-read and improving the two-hand coordination for the students.

- It has been concluded that the Nicolo Pasquali's "Lesson VIII" can be reorganized for the piano instrument 
and be used in the education as this work will bring the skills such as playing portato, playing legato, learning polyphony concept, doing ornaments, learning counterpoint technique, following themes, improving the ability to sight-read and improving the two-hand coordination for the students.

- It has been concluded that the Bernardo Pasquini's "Toccata" can be reorganized for the piano instrument and be used in the education as this work will bring the skills such as playing portato, playing legato, learning polyphony concept, learning counterpoint technique, following themes, playing two sounds in one hand, sounding different themes used at the same time, playing three sounds in one hand, improving the ability to sight-read and improving the two-hand coordination for the students.

- It has been concluded that the Ferdinando Pellegrini's "Sonata VI" can be reorganized for the piano instrument and be used in the education as this work will bring the skills such as playing legato, learning polyphony concept, following themes, playing two sounds in one hand, sounding different themes used at the same time, improving the ability to sight-read and improving the two-hand coordination for the students.

- It has been concluded that the Giovanni Battista Pergolesi's "Sonata in A Major" can be reorganized for the piano instrument and be used in the education as this work will bring the skills such as playing portato, playing legato, learning polyphony concept, doing ornaments, learning counterpoint technique, following themes, sounding different themes used at the same time, improving the ability to sight-read and improving the two-hand coordination for the students.

- It has been concluded that the Alessandro Poglietti's "Ricercare" can be reorganized for the piano instrument and be used in the education as this work will bring the skills such as playing portato, playing legato, learning polyphony concept, learning counterpoint technique, sounding different themes used at the same time and improving the two-hand coordination for the students.

- It has been concluded that the Francesco Pollarolo's "Sonata" can be reorganized for the piano instrument and be used in the education as this work will bring the skills such as playing portato, playing legato, learning polyphony concept, playing three sounds in one hand, learning counterpoint technique, following themes, playing two sounds in one hand and improving the two-hand coordination for the students.

- It has been concluded that the Nicola Antonio Porpora's "Fugue" can be reorganized for the piano instrument and be used in the education as this work will bring the skills such as playing portato, playing legato, learning polyphony concept, learning counterpoint technique, following themes, playing two sounds in one hand, sounding different themes used at the same time, improving the ability to sight-read and improving the two-hand coordination for the students.

- It has been concluded that the Michelangelo's "Toccata" can be reorganized for the piano instrument and be used in the education as this work will bring the skills such as playing portato, playing legato, learning polyphony concept, learning counterpoint technique, , playing two sounds in one hand and improving the two-hand coordination for the students.

- It has been concluded that the Domenico Scarlatti's "Sonata K.149" can be reorganized for the piano instrument and be used in the education as this work will bring the skills such as playing portato, playing legato, learning polyphony concept, doing ornaments, learning counterpoint technique, following themes, playing two sounds in one hand, sounding different themes used at the same time, doing silent finger cross, improving the ability to sight-read and improving the two-hand coordination for the students.

- It has been concluded that the Alessandro Scarlatti's "Toccata" can be reorganized for the piano instrument and be used in the education as this work will bring the skills such as playing portato, playing legato, learning polyphony concept, doing ornaments, learning counterpoint technique, following themes, sounding different themes used at the same time, improving the ability to sight-read and improving the two-hand coordination for the students.

- It has been concluded that the Giacomo Sellitto's "Fugue" can be reorganized for the piano instrument and be used in the education as this work will bring the skills such as playing portato, playing legato, learning polyphony concept, doing ornaments, learning counterpoint technique, following themes, playing two sounds in one hand, sounding different themes used at the same time, improving the ability to sight-read and improving the two-hand coordination for the students.

- It has been concluded that even if the Giovanni Serini's “Allegro" reorganized for the piano instrument, this piece would not be suitable for piano education because of the lack of pedagogical achievements.

- It has been concluded that the Girolamo Sertori's "Toccata" can be reorganized for the piano instrument and 
be used in the education as this work will bring the skills such as playing portato, playing legato, learning polyphony concept, doing ornaments, learning counterpoint technique, following themes, playing two sounds in one hand, sounding different themes used at the same time, improving the ability to sight-read and improving the two-hand coordination for the students.

- It has been concluded that the Bernardo Storace's "Toccata" can be reorganized for the piano instrument and be used in the education as this work will bring the skills such as playing portato, playing legato, learning polyphony concept, doing ornaments, learning counterpoint technique, following themes, playing two sounds in one hand, sounding different themes used at the same time and improving the two-hand coordination for the students.

- It has been concluded that the Giovanni Maria Trabaci's "Galliard I" can be reorganized for the piano instrument and be used in the education as this work will bring the skills such as playing portato, playing legato, learning polyphony concept, doing ornaments, learning counterpoint technique, sounding different themes used at the same time, improving the ability to sight-read and improving the two-hand coordination for the students.

- It has been concluded that the Domenico Zipoli's "Partita" can be reorganized for the piano instrument and be used in the education as this work will bring the skills such as playing portato, playing legato, learning polyphony concept, doing ornaments, learning counterpoint technique, following themes, playing two sounds in one hand, sounding different themes used at the same time, doing silent finger cross, improving the ability to sight-read and improving the two-hand coordination for the students.

- This research is limited to Italian baroque keyboard composers. So, it is recommended to research baroque composers in other areas too.

- This research is limited to one piece from each composer. So, it is recommended to research all works of composers and the piano repertoire should be expanded.

\section{References}

Bulut, D. (005). Müzik Eğitimi Anabilim Dalları Başlangıç Piyano Eğitiminde Uygulanan Yöntem ve Teknikler. Kayseri: Erciyes Üniversitesi Güzel Sanatlar Fakültesi Müzik Bölümü Müzik Sempozyumu.

Camp, M. W. (1992). Teaching Piano. California: Alfred Publishing Co.

Ekinci, H., \& Demirtaş, H. O. (2013). Barok Dönemi Piyano Eserlerini Yorumlamada Karşılaşılan Sorunlara İlişkin Müzik Öğretmeni Adaylarının Görüşleri. E-Journal of New World Sciences Academy. https://doi.org/10.12739/NWSA.2013.8.2.D0130

Ertem, Ş. (2011). Orta Düzey Piyano Eğitimi İçin Repertuar Seçme İlkeleri. Kastamonu: Kastamonu Eğitim Dergisi, 19(2), 645-652. https://doi.org/10.7816/sed-02-02-01

Eskioğlu, I. (2003). John Sebastian Bach'ın Envansiyonları'nın Piyano Eğitimi Dağarciğındaki Önemi ve Bu Yapttların Incelenmesi. Malatya: İnönü Üniversitesi Müzik Sempozyumu.

Gökbudak, S. (2013). Piyano Eğitiminde Öğretim Eserleri ve Basamakları. Piyano Öğretiminde Pedagojik Yaklaşımları Kitabı, Ankara: Pegem Akademi Yayınları.

Gültek, B. (2010). Avrupa Piyano Metodu Kullanım Kılavuzu. Erişim Tarihi: 12 Ekim 2013, Retrieved from http://www.piyanoegitimi.com/OgretmenRehberi.pdf

Günay, E., \& Uçan, A. (1980). Çevreden Evrene Keman Eğitimi I. Ankara: Dağarcık Yayınları.

Kasap, B. T. (2004). Müzik Öğretmeni Yetiştiren Kurumlardaki Yardımcı Çalgı Piyano Dersleri Üzerine Bir Araştırma. Isparta: 1924-2004 Musiki Muallim Mektebinden Günümüze Müzik Öğretmeni Yetiştirme Sempozyumu Bildirileri, Süleyman Demirel Üniversitesi.

Kutluk, Ö. (1996). Okul Şarkılarına Piyano İle Eşlik Yapabilme Becerisinin Geliştirilmesi Üzerine Bir Çalışma. Konya: Yayınlanmamış Yüksek Lisans Tezi, Selçuk Üniversitesi.

Lawshe, C. H. (1975). A quantitative approach to content validity. Personnel Psychology, 28, 563-575. https://doi.org/10.1111/j.1744-6570.1975.tb01393.x

Longyear, R. M. (1970). Principles of Neglected Musical Repertoire. Journal of Research in Music Education, 18(2), 167-177. https://doi.org/10.2307/3344269

Özmenteş, S. (2013). Çalgı Eğitiminde Öğrenci Motivasyonu ve Performans. Ankara: Eğitim ve Öğretim Araştırmaları Dergisi. 
Selanik, C. (1996). Müzik Sanatının Tarihsel Serüveni. Ankara: Doruk Yayımcılık.

Yücetoker, İ. (2014). J. S. Bach'ın Eğitim Yapıtlarından Olan Envansiyon ve Prelüd - Füglerin İncelenmesi. Akademik Bakış Dergisi, Kirgızistan, 31, 1-14.

Yücetoker, İ. (2014). John Stanley Volunterilerinin Piyano Eğitimi Repertuvarındaki Yeri ve Öneminin Incelenmesi (Yayınlanmamış Doktora Tezi, Gazi Üniversitesi Eğitim Bilimleri Enstitüsü, Ankara).

Yurdugül, H. (2005). Ölçek Geliştirme Çalışmalarında Kapsam Geçerliği İçin Kapsam Geçerlik İndekslerinin Kullanılması. XIV Ulusal Eğitim Bilimleri Kongresi, Denizli: Pamukkale Üniversitesi.

\section{Copyrights}

Copyright for this article is retained by the author(s), with first publication rights granted to the journal.

This is an open-access article distributed under the terms and conditions of the Creative Commons Attribution license (http://creativecommons.org/licenses/by/4.0/). 